\title{
POTENSI MODIFIKASI MODEL PIERS UNTUK PREDIKSI LUARAN IBU DENGAN PREEKLAMSIA PADA RUMAH SAKIT TIPE B DI INDONESIA: PENELITIAN RETROSPEKTIF DI RSUD ANSARI SALEH BANJARMASIN, KALIMANTAN SELATAN
}

\author{
Herdiantri Sufriyana $^{1}$, Lisda Handayani ${ }^{2}$, Fitri Yuliana ${ }^{3}$, Taufiq Syafi' ${ }^{4}$ \\ ${ }^{1,4}$ Fakultas Kedokteran Universitas Nahdlatul Ulama Surabaya \\ ${ }^{2}$ Akademi Kebidanan Sari Mulia Banjamasin \\ ${ }^{3}$ Sekolah Tinggi Ilmu Kesehatan Sari Mulia Banjarmasin \\ Email: herdiantrisufriyana@gmail.com
}

\begin{abstract}
Background: Preeclampsia is the most common cause (32\%) of maternal deaths in Indonesia. Model Piers (Pre-eclampsia Integrated Estimate Risk) can predict the outcomes / complications of pre-eclampsia and associated with a reduction in maternal morbidity. This study aims to assess the potential modification of the model to predict the outcome Piers mothers with preeclampsia in Type B hospitals in Indonesia. Methods: This research is a prognostic with the analytical method and quantitative approach retrospectively. This study used the capture technique stratified random sampling to obtain the medical records of 160 people with preeclampsia and 160 controls in hospitals Banjarmasin Ansari Saleh 2014. Identified availability of variables in the model along with the outer piers preeclampsia. Performed univariate, bivariate and multivariate corresponding availability of variables the model Piers. Result: eight of the 48 variables in the model Piers consistently found in all samples, while output available were complication preeclampsiaeclampsia and/or HELLP syndrome. The gestational age was significantly influent eclampsia for the subject in this study $(\mathrm{P}<0.05)$, HELLP syndrome $(\mathrm{P}<0.05)$, and a combination of both $(\mathrm{P}<0.01)$. Predictive value of a logistic regression model with the variables that the outer form of the syndrome HELLP or in combination with eclampsia is 0.811 (AUC ROC; CI 95\% from 0.636 to 0.986 ) and 0.767 (AUC ROC; CI 95\% 0.666 to $0.868)$, while the prediction of eclampsia was not significant ( $\mathrm{P}>0.05)$. Conclusion: Modifications Piers models to predict potential outcomes of women with preeclampsia in RS type B in Indonesia if it is supported by policies and standards that consider this model and supported a larger number of samples.
\end{abstract}

Keyword : Piers models, preeclampsia, eclampsia, HELLP syndrome

\section{PENDAHULUAN}

Angka kematian ibu di Indonesia tahun 2010 sebesar 220 per 100.000 kelahiran hidup jauh lebih besar daripada nilai tengah seluruh negara yang hanya mencapai 66 per 100.000 kelahiran hidup (WHO,2013). Salah satu penyebab terbanyak kesakitan dan kematian maternal dan perinatal adalah preeklamsia/eklamsia (24\%) selama kehamilan (UNFPA, 2014). Kematian maternal terjadi akibat kesakitan atau luaran yang buruk pada preeklamsia berupa eklamsia, sindroma HELLP, infark miokard, gagal ginjal akut dan abrupsio plasenta sesuai dengan konsensus Delphi (Milholland AV, dkk, 1973; Pill J, 1971), termasuk luaran perinatalnya yang dapat berupa BBLR dan IUFD (Lyall F, dkk, 2007).

Di Indonesia, preeklamsia menjadi penyebab terbanyak $(32 \%)$ kematian ibu setelah kasus perdarahan mulai dapat diatasi.Pelatihan bidan tampak efektif meningkatkan keterampilan mereka dalam menangani perdarahan di fasilitas pelayanan kesehatan primer dan sekunder sehingga perdarahan antepartum (3\%) maupun postpartum (20\%) telah turun ke posisi tiga dan empat penyebab kematian ibu di Indonesia (Kemenkes RI, 2014).Kematian ibu telah bergeser dari fasilitas pelayanan kesehatan primer dan sekunder ke tersier (Supratikto G, dkk, 2002; D'Ambruoso L, dkk, 2009). Penanganan ekspektatif yang tidak responsif pada wanita dengan preeklamsia pada pelayanan kesehatan tersier berperan dalam kematian ibu tersebut. Dengan demikian, kemampuan memprediksi luaran preeklamsia dalam jangka waktu yang cukup untuk melakukan tindakan akan mengoptimalkan penanganan ibu yang dirujuk dengan diagnosis preeklamsia.

Model PIERS (Pre-eclampsia Integrated Estimate RiSk), yaitu pemeriksaan dan surveilans preeklamsia dengan protokol yang dapat mengenali model inflamasi sistemik preeklamsia (Steegers EAP, dkk,2010), telah dihubungkan dengan penurunan angka kesakitan ibu (Menzies J, dkk, 2006). Model fullPIERS ini dirancang, dikembangkan dan telah divalidasi pada situasi 
fasilitas pelayanan kesehatan yang lengkap (von Dadelszen P, dkk, 2011).

Pada situasi dengan fasilitas yang kurang lengkap, model mini PIERS telah dikembangkan dan divalidasi di negara-negara berpendapatan rendah dan menengah (Firoz T, dkk, 2011). Namun, pusat pelayanan kesehatan tersier di Indonesia, dan dukungan jaminan kesehatan dari pemerintah untuk masyarakat berpendapatan rendah, telah meningkatkan potensi penggunaan model PIERS dengan menggunakan beberapa peubah pada model fullPIERS tetapi dengan jumlah yang lebih lengkap daripada miniPIERS. Jika modifikasi model PIERS ini memiliki nilai prediktif yang lebih baik daripada mini PIERS, maka modifikasi model ini dapat digunakan secara rutin sehingga dapat memiliki dampak terhadap angka kematian ibu di Indonesia. Penurunan angka kematian yang berkaitan dengan preeklamsia ini akan membantu Indonesia mencapai tujuan kelima MDG, yaitu menurunkan angka kematian ibu.

Penelitian ini bertujuan untuk menilai potensi modifikasi model PIERS untuk prediksi luaran ibu dengan preeklamsia pada rumah sakit tipe B di Indonesia. Diharapkan penelitian ini bermanfaat untuk mengembangkan modifikasi baru model PIERS yang dapat dikembangkan dan divalidasi lebih lanjut di beberapa rumah sakit umum pusat di Indonesia sehingga meningkatkan respon penanganan ekspektatif preeklamsia dan mengurangi angka kematian ibu akibat luaran preeklamsia yang buruk.

Tabel 1. Peubah-peubah dalam model PIERS (von Dadelszen, dkk, 2011).

1. Demografi

a. Usia maternal saat taksiran partus (tahun)

b. Jumlah janin (n)

c. Usia kehamilan saat memenuhi kriteria subjek penelitian pertama kali (minggu)

d. Usia kehamilan saat bersalin (minggu)

e. Berat badan saat masuk rumah sakit $(\mathrm{kg})$

f. Indeks massa tubuh $\left(\mathrm{kg} / \mathrm{m}^{2}\right)$

g. Graviditas (n)

h. Paritas (n)

i. Merokok pada kehamilan ini (ya/tidak)

2. Riwayat kehamilan dahulu

a. Hipertensi gestasional (ya/tidak)

b. Proteinuria gestasional (ya/tidak)

c. Diabetes melitus gestasional (kehamilan sebelumnya) (ya/tidak)

d. Diabetes melitus gestasional (kehamilan ini) (ya/tidak)

3. Riwayat penyakit dahulu

a. Hipertensi (ya/tidak)

b. Penyakit ginjal (ya/tidak)

c. Diabetes melitus (ya/tidak)
4. Gejala

a. Mual dan muntah berat (ya/tidak)

b. Nyeri kepala frontal (ya/tidak)

c. Gangguan penglihatan berupa pandangan kabur atau berbintang-bintang (ya/tidak)

d. Nyeri perut di kuadran kanan atas atau epigastrik (ya/tidak)

e. Nyeri dada/dispneu (ya/tidak)

f. Satu atau lebih gejala (ya/tidak)

5. Tanda kardiorespirasi

a. Tekanan darah diastolik saat memenuhi kriteria subjek penelitian pertama kali ( $\mathrm{mm}$ $\mathrm{Hg}$ )

b. Tekanan darah sistolik saat memenuhi kriteria subjek penelitian pertama kali ( $\mathrm{mm}$ $\mathrm{Hg}$ )

c. Rerata tekanan arteri saat memenuhi kriteria subjek penelitian pertama kali ( $\mathrm{mm}$ $\mathrm{Hg}$ )

d. Saturasi oksigen tanpa/dengan pemberian oksigen (\%)

6. Pemeriksaan hematologi

a. Hitung leukosit (x 109/L)

b. Hitung trombosit $\left(\mathrm{x} 10^{9} / \mathrm{L}\right)$

c. Rerata volum trombosit (fL)

d. Rasio rerata volum trombosit dan hitung trombosit

e. Waktu tromboplastin parsial teraktivasi dalam rasio ternormalisasi internasional (s)

f. Fibrinogen $(\mu \mathrm{mol} / \mathrm{L})$

7. Pemeriksaan fungsi ginjal

a. Dipstik (kategorik)

b. Dipstik (kontinu)

c. Protein urin 24 jam (g/hari)

d. Rasio protein urin dan kreatinin $(\mathrm{mg} / \mathrm{mmol})$

e. Kreatinin $(\mu \mathrm{mol} / \mathrm{L})$

f. Asam urat (mmol/L)

8. Pemeriksaan fungsi hati

a. Aspartat transaminase $(\mathrm{U} / \mathrm{L})$

b. Alanin transaminase (U/L)

c. Laktat dehidrogenase sebagai rasio terhadap titik tengah rentang normal lokal $(\mathrm{U} / \mathrm{L})$

d. Bilirubin $(\mu \mathrm{mol} / \mathrm{L})$

e. Albumin $(\mathrm{g} / \mathrm{L})$

f. Glukosa darah sewaktu (mmol/L)

9. Pemeriksaan janin

a. Detak jantung janin (normal/suspek/patologis)

b. Taksiran berat janin (kategori persentil)

c. Lingkar abdomen (kategori persentil)

d. Aliran akhir diastolik Doppler arteri umbilikus 


\section{METODE}

Penelitian ini dilaksanakan di RSUD Ansari Saleh Banjarmasin, Provinsi Kalimantan Selatan, Indonesia, sebagai salah satu rumah sakit tipe B di Indonesia, melalui tahapan-tahapan berikut. Pertama, peneliti mencatat nomer rekam medik pasien yang tercatat dengan diagnosis tertentu di dalam buku register pasien Instalasi Rawat Inap Bagian Kebidanan dan Penyakit Kandungan tahun 2014. Diagnosis yang dimaksud adalah preeklamsia ringan, preeklamsia berat, preeklamsia superimposed, Eklamsia, dan/atau sindroma HELLP.

Diketahui bahwa jumlah ibu memenuhi kriteria diagnosis tersebut adalah 292 orang (beberapa diagnosis tumpang tindih). Kemudian dilakukan pemilihan sampel dengan menggunakan teknik pengambilan stratified random sampling berdasarkan diagnosis terparah yang dicatat dengan urutan sebagai berikut: 1) preeklamsia ringan (65 orang atau 22,26\%); 2) preeklamsia berat (214 orang atau $73,29 \%$ ); 3) preeklamsia superimposed (13 orang atau $4,45 \%$ ); 4) eklamsia (23 orang atau $7,88 \%$ ); dan 5) sindroma HELLP (1 orang atau 0,34\%). Jumlah sampel penelitian ini adalah 160 orang disertai kontrol 160 orang dimana akan diambil pada masing-masingdiagnosis dengan proporsi sesuai prevalensi masing-masing seperti disebutkan di atas. Daftar nomer rekam medik sampel tersebut digunakan untuk mengambil rekam medik di Instalasi Rekam Medik. Peneliti mengidentifikasi ketersediaan data di dalam setiap rekam medik yang diambil. Peubah-peubah yang diukur pada penelitian ini menggunakan peubahpeubah dalam model PIERS (Preeclampsia Integrated Estimate of RiSk) yang dapat dilihat pada Tabel 1.

Peubah-peubah dalam model PIERS yang dipastikan tersedia secara konsisten dalam setiap rekam medik pasien yang memenuhi syarat juga diidentifikasi nilai peubahnya. Jika tidak tercatat, maka dimasukkan sebagai 'tidak ada'. Jika tercatat dan termasuk jenis data yang perlu dicatat nilai peubahnya, maka dimasukkan sesuai dengan nilai masing-masing. Peneliti memasukkan data ke pangkalan data melalui sistem informasi penelitian yang dirancang khusus untuk mengendalikan pengumpulan data oleh petugas lapangan. Analisis data dilakukan secara univariat, bivariat dan multivariat dengan SPSS versi 14.0Selain itu, juga diidentifikasi peubah berupa luaran kehamilan atau maternal. Luaran maternal yang digunakan mencakup kematian dan kesakitan pada sistem saraf pusat, kardiorespirasi, hepar, ginjal, atau hematologi (lihat Tabel 2). Luaran-luaran tersebut merupakan luaran maternal yang dikembangkan dalam konsensus Delphi (Milholland AV, dkk, 1973; Pill
J, 1971).

Tabel 2. Luaran maternal dari konsensus Delphi (Milholland AV, dkk, 1973; Pill J, 1971).

1. Kematian sebelum keluar rumah sakit (ya/tidak)

2. Sistem saraf pusat:

a. Eklamsia (ya/tidak)

b. Glasgow coma scale $<13$ (ya/tidak)

c. Strok atau defisit neurologis iskemia reversibel (ya/tidak)

d. Serangan iskemik transien (ya/tidak)

e. Kebutaan kortikal atau pelepasan retina (ya/tidak)

f. Ensefalopati posterior reversibel (ya/tidak)

3. Kardiorespirasi:

a. Bantuan inotropik positif (ya/tidak)

b. Pemberian infus dengan obat antihipertensi parenteral ketiga (ya/tidak)

c. Iskemia atau infark miokard (ya/tidak)

d. $\mathrm{SpO}_{2}<90 \%$ (ya/tidak)

e. $\mathrm{FiO}_{2} \geq 50 \%$, untuk $>1$ jam (ya/tidak)

f. Intubasi (selain untuk keperluan seksio sesarea) (ya/tidak)

g. Edema paru (ya/tidak)

4. Hematologi:

a. Transfusi produk darah (ya/tidak)

b. Hitung trombosit $<50 \times 10^{9} / \mathrm{L}$ tanpa transfusi (ya/tidak)

5. Hepar:

a. Disfungsi hepar (ya/tidak)

b. Hematoma atau ruptur hepar (ya/tidak)

6. Ginjal

a. Insufisiensi ginjal akut (kreatinin $>150$ $\mu \mathrm{mol} / \mathrm{L}$, tanpa penyakit ginjal sejak dahulu) (ya/tidak)

b. Gagal ginjal akut (kreatinin $>200 \mu \mathrm{mol} / \mathrm{L}$, dengan penyakit ginjal sejak dahulu) (ya/tidak)

c. Dialisis (ya/tidak)

7. Abrupsio plasenta (ya/tidak)

\section{HASIL DAN PEMBAHASAN}

Data peubah-peubah dalam model fullPIERS hanya ditemukan sebagian saja yang lengkap, yaitu 8 dari 48 peubah, pada 160 buah rekam medik ibu dengan preeklamsia di RSUD Ansari Saleh Banjarmasin tahun 2014 (lihat Tabel 3 di bawah). Data dianggap tersedia tanpa memandang nilai data itu sendiri. 
Kedelapan peubah tersebut adalah usia maternal saat taksiran partus, jumlah janin, usia kehamilan saat memenuhi kriteria subjek penelitian pertama kali, graviditas, paritas, dan tekanan darah diastolik maupun sistolik beserta rerata tekanan, arterisaat memenuhi kriteria subjek penelitian pertama kali.
Seluruh subjek penelitian bersalin dalam waktu kurang dari 24 jam setelah memenuhi kriteria subjek penelitian pertama kali sehingga usia kehamilan saat bersalin sama dengan usia kehamilan saat memenuhi kriteria subjek penelitian pertama kali.

Tabel 3. Ketersediaan data peubah-peubah dalam model fullPIERS pada rekam medik ibu dengan preeklamsia di RSUD Ansari Saleh Banjarmasin tahun 2014.

\begin{tabular}{|c|c|c|}
\hline Proporsi ketersediaan & $\begin{array}{c}\text { Jumlah data yang } \\
\text { tersedia } \\
\end{array}$ & Peubah \\
\hline & & Demografi \\
\hline $100,00 \%$ & 160 & $\begin{array}{c}\text { Usia maternal saat } \\
\text { taksiran partus (tahun) }\end{array}$ \\
\hline $100,00 \%$ & 160 & $\begin{array}{c}\text { Usia maternal saat } \\
\text { taksiran partus (tahun) }\end{array}$ \\
\hline $100,00 \%$ & 160 & $\begin{array}{c}\text { Usia maternal saat } \\
\text { taksiran partus (tahun) }\end{array}$ \\
\hline $100,00 \%$ & 160 & Jumlah janin (n) \\
\hline $100,00 \%$ & 160 & $\begin{array}{c}\text { Usia kehamilan saat } \\
\text { memenuhi kriteria subjek } \\
\text { penelitian pertama kali } \\
\text { (minggu) }\end{array}$ \\
\hline $100,00 \% *$ & 160 & $\begin{array}{c}\text { Usia kehamilan saat } \\
\text { bersalin (minggu) }\end{array}$ \\
\hline $0,00 \%$ & 0 & $\begin{array}{l}\text { Berat badan saat masuk } \\
\text { rumah sakit }(\mathrm{kg})\end{array}$ \\
\hline $0,00 \%$ & 0 & $\begin{array}{c}\text { Indeks massa tubuh } \\
\left(\mathrm{kg} / \mathrm{m}^{2}\right)\end{array}$ \\
\hline $100,00 \%$ & 160 & Graviditas (n) \\
\hline $100,00 \%$ & 160 & Paritas $(\mathrm{n})$ \\
\hline $0,00 \%$ & 0 & $\begin{array}{c}\text { Merokok pada kehamilan } \\
\text { ini (ya/tidak) }\end{array}$ \\
\hline- & - & $\begin{array}{c}\text { Riwayat kehamilan } \\
\text { dahulu }\end{array}$ \\
\hline $5,63 \%$ & 9 & $\begin{array}{l}\text { Hipertensi gestasional } \\
\text { (ya/tidak) }\end{array}$ \\
\hline $1,88 \%$ & 3 & $\begin{array}{c}\text { Proteinuria gestasional } \\
\text { (ya/tidak) }\end{array}$ \\
\hline $1,88 \%$ & 3 & $\begin{array}{c}\text { Diabetes melitus } \\
\text { gestasional (kehamilan } \\
\text { sebelumnya) (ya/tidak) }\end{array}$ \\
\hline $2,50 \%$ & 4 & $\begin{array}{c}\text { Diabetes melitus } \\
\text { gestasional (kehamilan } \\
\text { ini) (ya/tidak) } \\
\end{array}$ \\
\hline- & - & Riwayat penyakit dahulu \\
\hline $8,75 \%$ & 14 & Hipertensi (ya/tidak) \\
\hline $0,63 \%$ & 1 & Penyakit ginjal (ya/tidak) \\
\hline $1,88 \%$ & 3 & $\begin{array}{c}\text { Diabetes melitus } \\
(\mathrm{ya} / \text { tidak })\end{array}$ \\
\hline- & - & Gejala \\
\hline $61,25 \%$ & 98 & Mual dan muntah berat \\
\hline
\end{tabular}




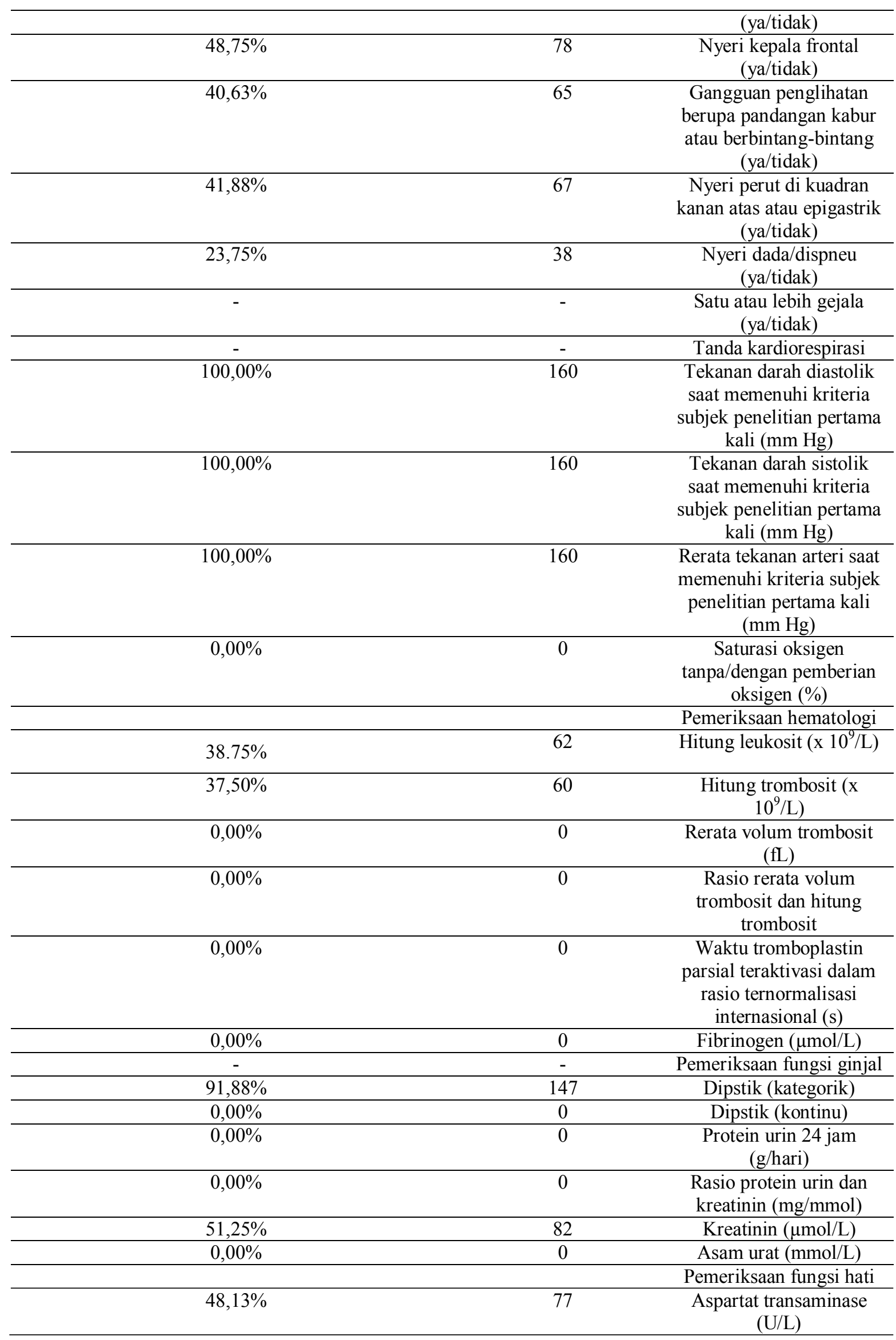




\begin{tabular}{ccc}
\hline $46,25 \%$ & 74 & Alanin transaminase (U/L \\
\hline $46,25 \%$ & 74 & $\begin{array}{c}\text { Alanin transaminase } \\
(\mathrm{U} / \mathrm{L})\end{array}$ \\
\hline $0,00 \%$ & 0 & $\begin{array}{c}\text { Laktat dehidrogenase } \\
\text { sebagai rasio terhadap } \\
\text { titik tengah rentang } \\
\text { normal lokal }(\mathrm{U} / \mathrm{L})\end{array}$ \\
\hline $0,00 \%$ & 0 & Bilirubin $(\mu \mathrm{mol} / \mathrm{L})$ \\
\hline $0,00 \%$ & 0 & Albumin $(\mathrm{g} / \mathrm{L})$ \\
\hline $63,13 \%$ & 101 & $\begin{array}{c}\text { Glukosa darah sewaktu } \\
\text { (mmol/L) }\end{array}$ \\
\hline $97,50 \%$ & 156 & Pemeriksaan janin \\
\hline $96,88 \%$ & 155 & $\begin{array}{c}\text { Detak jantung janin } \\
\text { (normal/suspek/patologis) }\end{array}$ \\
\hline $0,00 \%$ & $\begin{array}{c}\text { Taksiran berat janin } \\
\text { (kategori persentil) }\end{array}$ \\
\hline $0,00 \%$ & 0 & $\begin{array}{c}\text { Lingkar abdomen } \\
\text { (kategori persentil) }\end{array}$ \\
\hline & 0 & $\begin{array}{c}\text { Aliran akhir diastolik } \\
\text { Doppler arteri umbilicus }\end{array}$ \\
\hline
\end{tabular}

Keterangan: Semua persalinan terjadi dalam 24 jam setelah memenuhi kriteria subjek penelitian pertama kali.

Data-data luaran preeklamsia yang tersedia hanya berupa komplikasi eklamsia dan/atau sindroma HELLP yang tercatat pada 160 rekam medik ibu dengan preeklamsia di RSUD Ansari Saleh Banjarmasin tahun 2014 (lihat Tabel 4 di bawah).
Data dianggap tersedia tanpa memandang nilai data itu sendiri kecuali data eklamsia karena dianggap wajar tidak ditulis jika tidak eklamsia (tidak dapat dinilai proporsi ketersediaannya). Tidak ditemukan tulisan komplikasi lain, termasuk kematian.

Tabel 4. Ketersediaan data luaran preeklamsia pada rekam medik ibu dengan preeklamsia di RSUD Ansari Saleh Banjarmasin tahun 2014

\begin{tabular}{ccl}
\hline Proporsi ketersediaan & Jumlah data yang tersedia & Luaran \\
\hline $0,00 \%$ & 0 & $\begin{array}{l}\text { Kematian sebelum keluar rumah } \\
\text { sakit (ya/tidak) }\end{array}$ \\
\hline- & - & Sistem saraf pusat \\
\hline- & - & $\begin{array}{l}\text { a. Eklamsia (ya/tidak) } \\
\text { b. Glasgow coma scale }<13 \\
\text { (ya/tidak) }\end{array}$ \\
\hline- & - & $\begin{array}{l}\text { c. Strok atau defisit neurologis } \\
\text { iskemia reversibel (ya/tidak) }\end{array}$ \\
\hline- & - & $\begin{array}{l}\text { d. Serangan iskemik transien } \\
\text { (ya/tidak) }\end{array}$ \\
\hline- & $\begin{array}{l}\text { Kebutaan kortikal atau pelepasan } \\
\text { retina (ya/tidak) }\end{array}$ \\
\hline- & - & $\begin{array}{l}\text { Ensefalopati posterior reversibel } \\
\text { (ya/tidak) }\end{array}$ \\
\hline- & $\begin{array}{l}\text { Kardiorespirasi } \\
\text { Bantuan inotropik positif } \\
\text { (ya/tidak) }\end{array}$ \\
\hline- & - & $\begin{array}{l}\text { Pemberian infus dengan obat } \\
\text { antihipertensi parenteral ketiga }\end{array}$ \\
\hline
\end{tabular}




\begin{tabular}{|c|c|c|}
\hline & & (ya/tidak) \\
\hline- & - & $\begin{array}{l}\text { Iskemia atau infark miokard } \\
\text { (ya/tidak) }\end{array}$ \\
\hline- & - & $\mathrm{SpO}_{2}<90 \%$ (ya/tidak) \\
\hline- & - & $\begin{array}{l}\mathrm{FiO}_{2} \geq 50 \%, \text { untuk }>1 \text { jam } \\
\text { (ya/tidak) }\end{array}$ \\
\hline- & - & $\begin{array}{l}\text { Intubasi (selain untuk keperluan } \\
\text { seksio sesarea) (ya/tidak) }\end{array}$ \\
\hline \multirow[t]{2}{*}{-} & - & Edema paru (ya/tidak) \\
\hline & & Hematologi \\
\hline- & - & $\begin{array}{l}\text { Transfusi produk darah } \\
\text { (ya/tidak) }\end{array}$ \\
\hline \multirow[t]{2}{*}{$37,50 \% * *$} & 60 & $\begin{array}{l}\text { Hitung trombosit }<50 \times 10^{9} / \mathrm{L} \\
\text { tanpa transfusi (ya/tidak) }\end{array}$ \\
\hline & & Hepar \\
\hline $46,25 \% * *$ & 74 & Disfungsi hepar (ya/tidak) \\
\hline- & - & $\begin{array}{l}\text { Hematoma atau ruptur hepar } \\
\text { (ya/tidak) }\end{array}$ \\
\hline \multirow[t]{2}{*}{-} & - & Abrupsio plasenta (ya/tidak) \\
\hline & & Ginjal \\
\hline $51,25 \%$ & 82 & $\begin{array}{l}\text { Insufisiensi ginjal akut (kreatinin } \\
>150 \mu \mathrm{mol} / \mathrm{L}, \text { tanpa penyakit } \\
\text { ginjal sejak dahulu) (ya/tidak) }\end{array}$ \\
\hline $51,25 \%$ & 82 & $\begin{array}{l}\text { Gagal ginjal akut (kreatinin }>200 \\
\mu \mathrm{mol} / \mathrm{L} \text {, dengan penyakit ginjal } \\
\text { sejak dahulu) (ya/tidak) }\end{array}$ \\
\hline- & - & Dialisis (ya/tidak) \\
\hline- & - & Abrupsio plasenta (ya/tidak) \\
\hline
\end{tabular}

Rekam medik ibu dengan preeklamsia di RSUD Ansari Saleh Banjarmasin tahun 2014

Keterangan

*= Ditemukan 11 subjek penelitian yang mengalami eklamsia dan dianggap wajar jika tidak ditulis saat tidak ada eklamsia.

** = Ditemukan data tersebut yang memenuhi atau tidak memenuhi kriteria dan yang terdiagnosis atau tidak terdiagnosis sindroma HELLP.

- = Tidak dapat dinilai

Ketiga luaran preeklamsia yang diteliti adalah eklamsia, sindroma HELLP, dan komplikasi (eklamsia dan/atau sindroma HELLP). Ketiganya merupakan data kategorik nominal sehingga tidak dilakukan uji normalitas. Sedangkan kedelapan peubah PIERS yang dipilih terdiri atas 5 peubah berupa data kontinu rasio dan 3 peubah berupa data diskrit rasio. Dilakukan uji normalitas terhadap data kontinu rasio dan semuanya ditemukan tidak berdistribusi normal $(\mathrm{P} \leq 0,001)$ (lihat Tabel 5 di bawah). Pada analisis bivariat, ditunjukkan oleh Tabel 5 di bawah besar efek minimal yang dianggap berbeda dengan jumlah sampel 160 buah. Perhitungan didapat dari rumus sampel untuk analisis bivariat masing-masing peubah terhadap data luaran preeklamsia yang berskala data sama. Diantara kedelapan peubah PIERS yang dipilih, hanya usia kehamilan saat memenuhi kriteria subjek penelitian.Pertama kali yang berpengaruh secara bermakna terhadap eklamsia $(\mathrm{P}=0,011)$, sindroma HELLP $(\mathrm{P}=0,017)$, dan komplikasi $(\mathrm{P}=0,001)$. Usia maternal saat taksiran partus berpengaruh secara bermakna terhadap kejadian eklamsia $(\mathrm{P}=$ 0,043). Sedangkan rerata tekanan arterisaat memenuhi kriteria subjek penelitian pertama kali berpengaruh secara bermakna terhadap kejadian sindroma HELLP $(\mathrm{P}=0,045)$. 
Tabel 5. Pengaruh masing-masing peubah dalam model PIERS yang tersedia terhadap luar preeklamsia yang tersedia di RSUD Ansari Saleh Banjarmasin.

\begin{tabular}{|c|c|c|c|c|c|c|}
\hline \multicolumn{4}{|c|}{ Analisis bivariat } & \multirow{2}{*}{$\begin{array}{c}\text { Analisis } \\
\text { univariat } \\
\text { Eklamsia = } \\
6,9 \%(\mathrm{n}=11) \\
\text { Tidak } \\
\text { eklamsia }= \\
93,1 \% \\
(\mathrm{n}=149)\end{array}$} & \multirow{2}{*}{$\begin{array}{c}\text { Uji } \\
\text { normalita } \\
\text { s K-S } \\
\\
-\end{array}$} & \multirow{2}{*}{$\begin{array}{c}\begin{array}{c}\text { Peubah / } \\
\text { skala } \\
\text { data }\end{array} \\
\\
\text { Eklamsia } \\
\text { (ya/tidak) / } \\
\text { kategorik } \\
\text { nominal }\end{array}$} \\
\hline Komplikasi & HELLP & Eklamsia & $\begin{array}{c}\text { Besar efek } \\
\text { minimal } \\
\text { yang } \\
\text { dianggap } \\
\text { berbeda } \\
(\mathbf{n}=160)\end{array}$ & & & \\
\hline Komplikasi & HELLP & Eklamsia & $\begin{array}{l}\text { Besar efek } \\
\text { minimal } \\
\text { yang } \\
\text { dianggap } \\
\text { berbeda } \\
(\mathbf{n}=160)\end{array}$ & $\begin{array}{c}\text { HELLP }= \\
3,1 \%(\mathrm{n}=5) \\
\text { Tidak } \\
\text { komplikasi }= \\
96,9 \% \\
(\mathrm{n}=155)\end{array}$ & - & $\begin{array}{c}\text { HELLP } \\
\text { (ya/tidak) / } \\
\text { kategorik } \\
\text { nominal }\end{array}$ \\
\hline Komplikasi & HELLP & Eklamsia & $\begin{array}{c}\text { Besar efek } \\
\text { minimal } \\
\text { yang } \\
\text { dianggap } \\
\text { berbeda } \\
(\mathbf{n}=160)\end{array}$ & $\begin{array}{c}\text { Komplikasi = } \\
9,4 \%(\mathrm{n}=15) \\
\text { Tidak } \\
\text { komplikasi }= \\
90,6 \% \\
(\mathrm{n}=145)\end{array}$ & - & $\begin{array}{c}\text { Komplikasi } \\
\text { (ya/tidak)/ } \\
\text { kategorik } \\
\text { nominal }\end{array}$ \\
\hline $\mathrm{P}=0,098$ & $P=0,546$ & $\mathrm{P}=0,043^{*}$ & 2,21 tahun & $\begin{array}{c}31,10(14,59 \\
-43,21) \\
\text { tahun }\end{array}$ & $P=0,001$ & $\begin{array}{c}\text { Usia } \\
\text { maternal saat } \\
\text { taksiran } \\
\text { partus } \\
\text { (tahun)/ } \\
\text { kontinu rasio }\end{array}$ \\
\hline $\mathrm{P}=0,001^{*}$ & $\mathrm{P}=0,017^{*}$ & $\mathrm{P}=0,011^{*}$ & 1,28 minggu & $\begin{array}{c}38(24-43) \\
\text { minggu }\end{array}$ & $\mathrm{P}<0,001$ & $\begin{array}{c}\text { Usia } \\
\text { kehamilan } \\
\text { saat } \\
\text { memenuhi } \\
\text { kriteria } \\
\text { subjek } \\
\text { penelitian } \\
\text { pertama kali } \\
\text { (minggu) / } \\
\text { kontinu rasio }\end{array}$ \\
\hline $\mathrm{P}=0,192$ & $P=0,069$ & $\mathrm{P}=0,879$ & $5,65 \mathrm{~mm} \mathrm{Hg}$ & $\begin{array}{c}100(80- \\
210) \mathrm{mm} \mathrm{Hg}\end{array}$ & $\mathrm{P}<0,001$ & $\begin{array}{c}\text { Tekanan } \\
\text { darah } \\
\text { diastolik saat } \\
\text { memenuhi } \\
\text { kriteria } \\
\text { subjek } \\
\text { penelitian } \\
\text { pertama kali } \\
\text { (mm Hg) / } \\
\text { kontinu rasio }\end{array}$ \\
\hline $\mathrm{P}=0,352$ & $\mathrm{P}=0,045^{*}$ & $\mathrm{P}=0,463$ & $5,73 \mathrm{~mm} \mathrm{Hg}$ & $\begin{array}{c}123(90- \\
213) \mathrm{mm} \\
\mathrm{Hg}\end{array}$ & $\mathrm{P}<0,001$ & $\begin{array}{c}\text { Rerata } \\
\text { tekanan arteri } \\
\text { saat } \\
\text { memenuhi } \\
\text { kriteria }\end{array}$ \\
\hline
\end{tabular}




\begin{tabular}{|c|c|c|c|c|c|c|}
\hline & & & & & & $\begin{array}{c}\text { subjek } \\
\text { penelitian } \\
\text { pertama kali } \\
\text { (mm Hg)/ } \\
\text { kontinu rasio }\end{array}$ \\
\hline $\mathrm{P}=0,241$ & $\mathrm{P}=0,945$ & $\mathrm{P}=0,165$ & 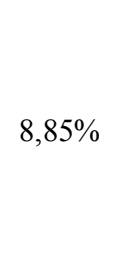 & $\begin{array}{c}\text { Modus }=1 \\
1=1,9 \% \\
(n=3) \\
2=95,6 \% \\
(n=153) \\
3=2,5 \% \\
(n=4)\end{array}$ & - & $\begin{array}{c}\text { Jumlah janin } \\
\text { (n) / diskrit } \\
\text { rasio }\end{array}$ \\
\hline$P=0,206$ & $\mathrm{P}=0,823$ & $P=0,090$ & $15,33 \%$ & $\begin{array}{c}\text { Modus }=2 \\
1=29,4 \% \\
(\mathrm{n}=47) \\
2=33,1 \% \\
(\mathrm{n}=53) \\
3=20,6 \% \\
(\mathrm{n}=33) \\
4=10,0 \% \\
(\mathrm{n}=16) \\
5=3,8 \% \\
(\mathrm{n}=6) \\
6=1,3 \% \\
(\mathrm{n}=2) \\
7=0,0 \% \\
(\mathrm{n}=0) \\
8=1,9 \% \\
(\mathrm{n}=3)\end{array}$ & - & $\begin{array}{l}\text { Graviditas } \\
\text { (n) / diskrit } \\
\text { rasio }\end{array}$ \\
\hline$P=0,075$ & & & & $\begin{array}{c}\text { Modus }=1 \\
0=31,3 \% \\
(\mathrm{n}=50) \\
1=40,0 \% \\
(\mathrm{n}=64) \\
2=17,5 \% \\
(\mathrm{n}=28) \\
3=8,1 \% \\
(\mathrm{n}=13) \\
4=1,3 \% \\
(\mathrm{n}=2) \\
5=0,6 \% \\
(\mathrm{n}=1) \\
6=0,0 \% \\
(\mathrm{n}=0) \\
7=1,3 \% \\
(\mathrm{n}=2)\end{array}$ & - & $\begin{array}{l}\text { Paritas (n) / } \\
\text { diskrit rasio }\end{array}$ \\
\hline
\end{tabular}

$*=$ Bermakna secara statistik dengan $\alpha=0,05$.

$\mathrm{K}-\mathrm{S}=$ Kolmogorov-Smirnov

- = Tidak dapat dinilai

Analisis regresi logistik hanya dapat dilakukan dengan satu peubah independen terhadap masingmasing peubah dependen, yaitu ketiga luaran preeklamsia, karena besar sampel 160 buah hanya dapat memenuhi besar minimal regresi logistik untuk satu peubah independen. Modifikasi model PIERS, yang dihasilkan dari regresi logistik, ditunjukkan oleh Tabel 6 di bawah. Model dengan luaran eklamsia tidak signifikan $(\mathrm{P}=0,146)$
Berdasarkan analisis Nagelkerke R2, hanya 17,4\% luaran sindroma HELLP dan 10,7\% luaran

komplikasi yang dapat dijelaskan oleh model masing-masing.

Nilai prediktif model dengan luaran sindroma HELLP dan komplikasi adalah 0,811 (AUC ROC; IK 95\% 0,636 - 0,986; lihat Gambar 1) dan 0,767 (AUC ROC; IK 95\% 0,666 - 0,868; lihat Gambar $1)$. 
Pada titik puncak ROC masing-masing, ditemukan nilai potong dengan sensitifitas dan spesifisitas optimal pada model dengan luaran sindroma HELLP $(\mathrm{P}=0,20)$ dan komplikasi $(\mathrm{P}=$ 0,82). Pada titik potong tersebut, sensitifitas ditemukan $80,00 \%$ dan $73,30 \%$ pada model dengan luaran sindroma HELLP dan komplikasi, sedangkan spesifisitas ditemukan $67,70 \%$ dan $70,30 \%$ pada model dengan luaran sindroma HELLP dan komplikasi.

Tabel 6. Nilai prediktif modifikasi model PIERS sesuai ketersediaan peubah di RSUD Ansari Saleh Banjarmasin.

\begin{tabular}{|c|c|c|c|c|c|c|}
\hline Spesifisitas & Sensitifitas & $\begin{array}{c}\text { Nilai } \\
\text { potong }\end{array}$ & IK 95\% & $\begin{array}{l}\text { AUC } \\
\text { ROC }\end{array}$ & $\begin{array}{c}\text { Nagelkerke } \\
\mathbf{R}^{\mathbf{2}}\end{array}$ & $\begin{array}{l}\text { Modifikasi model } \\
\text { PIERS }\end{array}$ \\
\hline- & - & - & - & - & - & $\begin{array}{l}\text { Model dengan luaran } \\
\text { eklamsia tidak signifikan } \\
(\mathrm{P}=0,146)\end{array}$ \\
\hline \multirow[t]{3}{*}{$67,70 \%$} & $80,00 \%$ & $\mathrm{P}=0,20$ & $\begin{array}{c}0,636- \\
0,986\end{array}$ & 0,811 & $17,4 \%$ & $\begin{array}{l}\text { Model dengan luaran } \\
\text { HELLP: }\end{array}$ \\
\hline & & & & & & $\begin{array}{l}\operatorname{Logit}(y)=g=4,432- \\
0,229 x(P=0,009)\end{array}$ \\
\hline & & & & & & $\begin{array}{l}\text { Keterangan: } \\
\mathrm{y}=\text { HELLP } \\
\mathrm{x}=\text { usia kehamilan saat } \\
\text { memenuhi kriteria subjek } \\
\text { penelitian pertama kali }(\mathrm{P} \\
=0,008)\end{array}$ \\
\hline \multirow[t]{3}{*}{$70,30 \%$} & $73,30 \%$ & $\mathrm{P}=0,82$ & $\begin{array}{c}0,666- \\
0,868\end{array}$ & 0,767 & $10,7 \%$ & $\begin{array}{l}\text { Model dengan seluruh } \\
\text { luaran (komplikasi): }\end{array}$ \\
\hline & & & & & & $\begin{array}{l}\operatorname{Logit}(y)=g=3,471- \\
0,161 \times(P=0,004)\end{array}$ \\
\hline & & & & & & $\begin{array}{l}\text { Keterangan: } \\
\mathrm{y}=\text { komplikasi } \\
\mathrm{x}=\text { usia kehamilan saat } \\
\text { memenuhi kriteria subjek } \\
\text { penelitian pertama kali ( } \mathrm{P} \\
=0,003)\end{array}$ \\
\hline
\end{tabular}

- = Tidak dapat dinilai

Dikembangkan dengan data lengkap dari 1.935 ibu dengan preeklamsia, fullPIERS mampu memprediksi luaran maternal dalam 48 jam sejak terdiagnosis preeklamsia (AUC ROC 0,88 dengan rentang 0,84-0,92 dan tingkat kepercayaan 95\%). Akurasi klasifikasi fullPIERS cukup baik. Sebagai contoh, dengan menggunakan probabilitas terprediksi 0,05 sebagai ambang batas, fullPIERS dapat mengidentifikasi $75 \%$ ibu yang mengalami luaran sehingga masuk ke dalam kelompok risiko tinggi, dan hanya $16 \%$ populasi yang salah diidentifikasi sebagai kelompok risiko tinggi. Pada penerapannya, probabilitas terprediksi paling baik digunakan sebagai nilai kontinu untuk merancang penanganan.

FullPIERS juga cukup baik untuk prediksi luaran maternal dari 2 hingga 7 hari setelah terdiagnosis (AUC ROC $>0,7$ ). Temuan AUC dan 
stratifikasi risiko ini diulang untuk ibu yang masuk dengan preeklamsia sebelum 34 minggu (AUC ROC 0,85 dengan rentang 0,79-0,92 dan tingkat kepercayaan 95\%). Nilai AUC ROC untuk fullPIERS adalah 0,77 (rentang 0,45-1,00 dan tingkat kepercayaan 95\%) untuk ibu yang masuk dengan preeklamsia ke pusat pelayanan obstetrik level 1 atau 2 (enam luaran pada $139 \mathrm{ibu}$ ), dan 0,80 (rentang 0,66-0,94 dan tingkat kepercayaan 95\%) untuk ibu yang masuk dengan preeklamsia ke pusatpusat obstetrik di negara-negara berpendapatan rendah dan menengah (17 luaran pada 145 wanita).

Kelemahan fullPIERS ini adalah baru dilakukan di negara berpendapatan tinggi pada fasilitas pelayanan obstetrik dengan ibu yang memenuhi definisi riset untuk preeklamsia sehingga terbatas penggunaannya. Namun,sekarang sudah mulai dikembangkan model PIERS pada hipertensi dalam kehamilan dengan menggunakan gejala dan tanda yang spesifik. Model yang disebut sebagai miniPIERS ini dapat digunakan di daerah pedesaan pada negara berpendapatan tinggi, menengah maupun rendah (Payne BA, dkk, 2014). FullPIERS dibatasi pada surveilans ibu dan tidak diarahkan untuk menilai risiko perinatal akibat preeklamsia (Steegers EAP, dkk, 2010).

Von Dadelszen dkk (2011) merekomendasikan penggunaan usia kehamilan, gejala, oksimetri nadi, kreatinin, hitung trombosit, dan aspartat transaminase untuk digunakan dalam melakukan stratifikasi risiko maternal selama penilaian dan surveilans ibu dengan preeklamsia. Probabilitas turunan fullPIERS tersebut memiliki karakteristik kemampuan yang serupa dengan model yang menggambarkan sistem kardiovaskular dan perawatan intensif (Knuiman MW, dkk, 1997; Richardson DK, dkk, 2001; Zimmerman JE, dkk, 2006). Pemeriksaan aspartat transaminase, alanin transaminase,

dan laktat dehidrogenase dapat diganti dengan aspartat transaminase saja tanpa harus kekurangan manfaat informasi yang diberikannya dan dapat mengurangi biaya laboratorium.

Dalam penelitian ini, ditemukan bahwa tidak semua peubah dalam model fullPIERS tersedia pada rekam medik ibu dengan preeklamsia di RSUD Ansari Saleh Banjarmasin tahun 2014 sebagai satu dari banyak RS tipe B di Indonesia. Diduga ketidaktersediaan peubah ini disebabkan penulisan rekam medik yang tidak selalu konsisten dengan tindakan pemeriksaan yang dilakukan.

Dugaan tersebut timbul dari anggapan bahwa beberapa peubah seharusnya sudah menjadi tindakan pemeriksaan obstetrik rutin di RS meskipun tidak menggunakan model PIERS dalam prosedur pelayanannya. Misalnya, peubah seperti berat badan, tinggi badan (berat badan dan tinggi badan dapat digunakan untuk menghitung IMT), detak jantung janin dan taksiran berat janin, sudah rutin digunakan dalam pemeriksaan obstetrik di RS tetapi tidak dilakukan dan/ atau ditulis secara konsisten di rekam medik.

Selain itu, penelitian ini memang mengi dentifikasi penulisan beberapa gejala dan tanda tanpa memandang apakah hasilnya positif atau negatif.

Data gejala dan tanda yang ditemukan tidak selalu positif dan sebagian diantaranya juga negatif tetapi tetap dianggap tersedia. Misalnya, riwayat kehamilan dahulu seperti hipertensi gestasional, proteinuria gestasional, dan diabetes melitus gestasional pada kehamilan sebelumnya maupun sekarang,serta riwayat penyakit dahulu dan gejalagejala preeklamsia berat atau yang lebih parah, hanya tersedia sebagian dan dapat berarti tidak dilakukan dan/atau ditulis. Hal yang serupa terjadi pada data-data pemeriksaan penunjang. Sebagian pemeriksaan penunjang seperti pemeriksaan hematologi, fungsi ginjal, fungsi hati, dan pemeriksaan janin, kecuali rerata volum trombosit beserta rasio terkait, dipstik kontinu, dan protein urin 24 jam beserta rasio terkait, dapat dilakukan di RSUD Ansari Saleh Banjarmasin sesuai permintaan dokter tetapi belum menjadi prosedur tetap pada kasus preeklamsia.

Tidak ada luaran preeklamsia berupa kematian dan abrupsio plasenta yang tercatat pada rekam medik ibu dengan preeklamsia di RSUD Ansari Saleh Banjarmasin tahun 2014. Luaran preeklamsia yang ditemukan hanya berupa eklamsia dan/atau sindroma HELLP. Tidak ditemukan catatan GCS, konsultasi spesialis penyakit saraf beserta pemeriksaan neurologis, dan diagnosis kebutaan pada luaran preeklamsia di sistem saraf pusat. Tidak ditemukan catatan terkait kardiorespirasi kecuali tekanan darah, frekuensi nadi dan laju nafas. Bahkan, tidak ditemukan catatan $\mathrm{SpO} 2<90 \%$. Perlu diperhatikan bahwa penelitian ini melihat catatan bidan pada rekam medik. Namun, hal tersebut disarankan untuk dilakukan secara rutin pada kasus preeklamsia agar meningkatkan respon bidan sebagai tenaga kesehatan yang mengobservasi pasien secara langsung sehingga memberikan informasi yang lebih lengkap kepada dokter yang menangani.

Terdapat pula luaran preeklamsia yang tergambar dari pemeriksaan penunjang yang dilakukan pada hematologi, fungsi ginjal, dan fungsi hati. Namun, hal ini belum dilakukan terfokus pada model prediksi tertentu.

Berdasarkan ketersediaan data peubah-peubah dalam model fullPIERS dan luaran preeklamsia tersebut, model PIERS memiliki potensi untuk diterapkan. Ketersediaan data ini diduga dipengaruhi oleh kebijakan yang diambil dalam pelayanan obstetrik di rumah sakit. Data tersedia tetapi tidak seragam dilakukan pada semua pasien 
preeklamsia, atau setidaknya pada pasien preeklamsia berat atau preeklamsia onset dini karena risiko komplikasi yang lebih berat dan komplikasi ini memperantarai kejadian kematian yang berpeluang lebih tinggi. Keseragaman pemeriksaan dapat didorong melalui kebijakan dan standarisasi yang tertulis dan disepakati, termasuk kesepakatan istilah luaran preeklamsia atas berbagai komplikasi yang mungkin terjadi.

Sebagai penyakit yang berdampak pada banyak sistem, penetapan luaran disarankan tidak terpisah pada sistem saraf pusat secara terpisah (eklamsia) atau sistem-sistem lain secara tergabung (sindroma HELLP) karena kelainan pemeriksaan dapat terjadi tidak hanya pada satu sistem organ, dan tidak pasti pula terjadi bersama-sama pada organ darah dan hati, sebagaimana terjadi pada sindroma HELLP.

Diagnosis eklamsia dan/atau sindroma HELLP mungkin dapat tidak/belum tegak tetapi risiko tinggi kejadian keduanya harus terdeteksi lebih dulu sehingga tindakan tidak bersifat ekspektan saja.

Berdasarkan hasil penelitian di RSUD Ansari Saleh Banjarmasin ini, rumah sakit tipe B tersebut belum dapat menyediakan data untuk model PIERS.

Generalisasi pada rumah sakit tipe B lain jelas memerlukan validasi di lebih banyak rumah sakit dengan penelitian yang terintegrasi dengan pelayanan. Penelitian ini menunjukkan bahwa terdapat potensi penggunaan model PIERS pada rumah sakit tipe B jika didukung dengan kebijakan dan standarisasi. Penelitian ini juga menunjukkan bahwa modifikasi model PIERS sesuai peubah yang tersedia, sebagaimana dimiliki oleh rumah sakit ini, belum membentuk model yang mampu memprediksi luaran preeklamsia yang buruk. Namun, meskipun tidak lengkap, modifikasi model PIERS diduga tetap dapat dilakukan jika digunakan peubah yang lebih banyak dan divalidasi pada sampel yang lebih besar agar memenuhi syarat analisis multivariat dengan peubah yang lebih banyak pula.Dengan besar sampel 160 orang, besar efek minimal yang dianggap berbeda relatif sudah cukup sempit tetapi hanya satu peubah yang dapat dilibatkan dalam model untuk analisis regresi. Semua data rasio tidak terdistribusi normal dan memerlukan sampel yang lebih besar. Secara bivariat, hanya usia kehamilan saat memenuhi kriteria subjek penelitian pertama kali yang memiliki perbedaan secara bermakna antara kelompok eklamsia, sindroma HELLP dan komplikasi (tanpa memandang jenis komplikasi).

Preeklamsia onset dini memang memiliki risiko kejadian komplikasi yang lebih tinggi. Perbedaan bermakna tersebut tampaknya bersifat dua arah tetapi mekanismenya belum jelas.

Dalam penelitian ini, usia maternal saat taksiran partus ditemukan berpengaruhsecara bermakna terhadap kejadian eklamsia. Hal ini diduga diperantarai oleh pengaruh usia maternal tersebut terhadap kompliansi pembuluh darah dalam menjaga tekanan darah dalam batas yang normal. Namun demikian, hal ini perlu diteliti lebih lanjut dengan penelitian in vivo dan klinis secara tandem.

Hal yang menarik adalah rerata tekanan arteri justru hanya berbeda secara bermakna terhadap kejadian sindroma HELLP saja, tetapi tidak berbeda secara bermakna terhadap eklamsia ataupun komplikasi secara keseluruhan. Meskipun hanya berbeda tipis $(\mathrm{P}=0,045)$, temuan bahwa rerata tekanan arteri yang tidak berbeda secara bermakna justru bertentangan dengan dugaan bahwa usia maternal berpengaruh terhadap kompliansi pembuluh darah dan tekanan darah sehingga memperantarai kejadian eklamsia.

Tekanan darah sistolik juga memiliki perbedaan yang bermakna $(\mathrm{P}=0,028)$ tetapi tekanan darah diastolik justruk tidak berbeda secara bermakna. Hal ini berkebalikan dari teori selama ini bahwa tekanan darah diastolik lebih diperhatikan pada kasus preeklamsia. Namun demikian, mekanismenya masih belum jelas dan hal ini perlu diteliti lebih lanjut.

Meskipun hanya terdapat satu peubah yang eligibel untuk dimasukkan ke dalam model, tetap dilakukan analisis nilai prediktif atas model tersebut. Peubah yang dimasukkan ke dalam model tersebut adalah usia kehamilaan saat memenuhi kriteria subjek penelitian pertama kali. Model dengan luaran eklamsia tidak cukup signifikan untuk dianalisis tetapi model dengan luaran sindroma HELLP dan komplikasi secara keseluruhan masih dapat dianalisis. Kedua model dengan luaran HELLP dan komplikasi secara keseluruhan tersebut memiliki AUC ROC yang baik, berturut-turut yaitu 0,811 dan 0,767 tetapi hanya $17,4 \%$ dan $10,7 \%$ variasi prediksi yang dapat dijelaskan oleh model. Artinya, terdapat perbedaan antara kejadian nyata dengan yang diprediksi oleh model ini dan hanya sedikit proporsi kejadian yang berhubungan dengan peubah dalam model tersebut. Interval kepercayaan 95\% juga sangat lebar. Model tersebut digunakan dengan nilai potong 0,2 dan 0,82 untuk mendapatkan sensitifitas dan spesifisitas yang optimal.

Penelitian ini menunjukkan bahwa perlu data pasien yang lebih lengkap dan terfokus untuk dapat menggunakan model PIERS secara keseluruhan atau modifikasinya. Namun, modifikasi model PIERS masih mungkin digunakan jika penelitian dilakukan dengan sampel yang lebih besar dan terintegrasi dalam pelayanan dengan payung kebijakan dan standarisasi dari rumah sakit. Dengan demikian, model PIERS dapat divalidasi di Indonesia dan melengkapi validasi lain yang telah dilakukan di beberapa negara berpendapatan rendah dan menengah lainnya. 


\section{SIMPULAN}

Penelitian ini menunjukkan bahwa perlu data pasien yang lebih lengkap dan terfokus untuk dapat menggunakan model PIERS secara keseluruhan atau modifikasinya. Namun, modifikasi model PIERS masih mungkin digunakan jika penelitian dilakukan dengan sampel yang lebih besar dan terintegrasi dalam pelayanan dengan payung kebijakan dan standarisasi dari rumah sakit. Dengan demikian, model PIERS dapat divalidasi di Indonesia dan melengkapi validasi lain yang telah dilakukan di beberapa negara berpendapatan rendah dan menengah lainnya.

\section{DAFTAR PUSTAKA}

D'Ambruoso L, Byass P, Qomariyah S. 2009. 'Maybe it was her fate and maybe she ran out of blood': final caregivers' perspectives on access to care in obstetric emergencies in rural Indonesia. J Biosoc Sci 42: 213-241.

Firoz T, Sanghvi H, Merialdi M, von Dadelszen P. 2011. Pre-eclampsia in low and middle income countries. Best Practice \& Research Clinical Obstetrics and Gynaecology 25: 537-548.

Kemenkes RI. 2014. Profil Kesehatan Indonesia Tahun 2013. [http://www.depkes.go.id/ resources/download/pusdatin/profil-

kesehatan-indonesia/profil-kesehatanindonesia-2013.pdf - diakses tanggal 1 September 2014].

Knuiman MW, Vu HT. 1997. Prediction of coronary heart disease mortality in Busselton, Western Australia: an evaluation of the Framingham, national health epidemiologic follow up study, and WHO ERICA risk scores. J Epidemiol Community Health; 51: 515-19.

Lyall F, Belfort M. 2007. Pre-eclampsia: Etiology and clinical practice. 1st edition. New York: Cambridge University Press.

Menzies J, Magee LA, Li J, Yin R, Lam E, Stuart $\mathrm{H}$, dkk. 2006. Instituting surveillance guidelines and adverse outcomes in preeclampsia: a single site study. Obstet Gynecol 110: 121-27.

Milholland AV, Wheeler SG, Heieck JJ. 1973. Medical assessment by a Delphi group opinion technic. N Engl J Med; 288: 127275.

Payne BA, Hutcheon JA, Ansermino JM, dkk. 2014. Prediction of adverse maternal outcomes in pre-eclampsia: development and validation of the fullPIERS model. PLOS Medicine 11(1): 1-13.

Pill J. 1971. The Delphi method: substance, context, a critique and an annotated bibliography. Socioecon Plann Sci; 5: 57-71.

Richardson DK, Corcoran JD, Escobar GJ, Lee SK. 2001. SNAP-II and SNAPPE-II: simplified newborn illness severity and mortality risk scores. J Pediatr; 138: 92-100.

Supratikto G, Wirth ME, Achadi E, Cohen S, Ronsmans C. 2002. A district-based audit of the causes and circumstances of maternal deaths in South Kalimantan, Indonesia. Bull World Health Organ 80: 228-234.

Steegers EAP, von Dadelszen P, Duvekot JJ, Pijnenborg R. 2010. Pre-eclampsia. Lancet; 376: 631-44.

UNFPA. 2014. Issues and Challenges: Maternal Mortality Ratio. [http://indonesia.unfpa.org/issues-andchallenges/maternal-mortality-ratio accessed on March 1st, 2015].

von Dadelszen P, Payne B, Li J, dkk. 2011. Prediction of adverse maternal outcomes in pre-eclampsia: development and validation of the fullPIERS model. Lancet 377: 219-27.

WHO. 2013. World Health Statistics 2013. [http://www.who.int/gho/publications/world health_statistics/EN_WHS2013 Full.pdf -

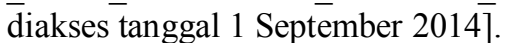

Zimmerman JE, Kramer AA, McNair DS, Malila FM. 2006. Acute Physiology and Chronic Health Evaluation (APACHE) IV: hospital mortality assessment for today's critically ill patients. Crit Care Med; 34: 1297-310 